\title{
Pengaruh Due Professional Care, Akuntabilitas, dan Kecerdasan Emosional Pada Kualitas Audit dengan Reward Sebagai Pemoderasi
}

\author{
Putu Kemala Vidyantari ${ }^{1}$ \\ I Dewa Gede Dharma Suputra ${ }^{2}$
}

\author{
${ }^{1}$ Fakultas Ekonomi dan Bisnis Universitas Udayana (Unud), Bali, Indonesia \\ email: vkemala@yahoo.com/Tlp: +6282247135090 \\ ${ }^{2}$ Fakultas Ekonomi dan Bisnis Universitas Udayana (Unud), Bali, Indonesia
}

\begin{abstract}
ABSTRAK
Penelitian ini bertujuan untuk menguji secara empiris bahwa reward memoderasi pengaruh due professional care, akuntabilitas, dan kecerdasan emosional pada kualitas audit. Sampel yang digunakan adalah seluruh auditor yang bekerja di Kantor Akuntan Publik (KAP) Provinsi Bali dengan menggunakan metode nonprobability sampling dengan teknik sampel jenuh dengan jumlah sampel 47 auditor. Pengumpulan data dilakukan dengan metode survei teknik kuesioner dan teknik analisis data yaitu uji Moderated Regression Analysis (MRA). Hasil analisis menunjukkan bahwa reward memperkuat pengaruh due professional care, akuntabilitas, dan kecerdasan emosional pada kualitas audit. Hal ini menunjukkan jika due professional care, akuntabilitas, dan kecerdasan emosional seorang auditor semakin baik dan didukung dengan pemberian reward yang sesuai menghasilkan kualitas audit yang lebih baik.

Kata kunci: Kualitas audit, due professional care, akuntabilitas, kecerdasan emosional, reward
\end{abstract}

\begin{abstract}
This study aimed to get empirical evidence rewards as the moderating influence of due professional care, accountability, and emotional intelligence on audit quality. The sample is all the auditors who work in KAP province of Bali. The sampling method by using nonprobability sampling with saturated sample technique and the total is 47 auditor. Data was collected by questionnaire with survey technique and data analysis technique is Moderated Regression Analysis (MRA). The results of the analysis show that rewards strengthen the influence of due care professional, accountability, and emotional intelligence on audit quality. If due care professional, accountability, and emotional intelligence increases then audit quality level gets higher and better with the supporteof reward.

Keywords: Audit quality, due professional care, accountability, emotional intelligence, reward
\end{abstract}




\section{PENDAHULUAN}

Akuntan publik adalah salah satu profesi yang menentukan keberadaan suatu perusahaan dimata publik. Tanggung jawab utama akuntan publik atau auditor independen adalah melakukan fungsi pengauditan atas pelaporan keuangan yang diterbitkan oleh manajemen perusahaan. Pengguna laporan keuangan khususnya bagi investor dan kreditor tentu mengharapkan penilaian yang tidak memihak dan objektif terhadap informasi yang tersaji dalam laporan keuangan yang disusun oleh manajemen. Sehingga, peran auditor sebagai pihak yang memiliki fungsi untuk mampu meningkatkan level keandalan laporan keuangan dapat meningkatkan kepercayaan semua pihak yang berkepentingan dengan perusahaan tersebut. Auditor yang selalu bersifat jujur dan independen cenderung memiliki kualitas audit yang baik.

Beberapa kasus membuktikan bahwa jasa audit oleh kantor akuntan publik (KAP) tidak selalu menghasilkan kualitas audit yang baik. Salah satunya pada peristiwa PT Kimia Farma Tbk. (KAEF) dalam kasus mark up laba bersih yang menimbulkan penggelembungan laba bersih ditahun 2001 senilai Rp 32,7 miliar. Kasus ini berakhir dengan ditetapkannya sanksi oleh Bapepam berupa denda sebesar Rp 1 M kepada direksi Kimia Farma periode 1998- Juni 2002, Rp 100 juta kepada auditor Hans Tuanakotta \& Mustafa sebesar, dan Rp 500 juta kepada perusahaan Kimia Farma.

Pada tahun 2005 Bapepam-LK (Badan Pengawas Pasar Modal dan Lembaga Keuangan) menyidik akuntan publik yang mengaudit laporan keuangan PT Great River International, Tbk. Yang ditemukan adanya indikasi konspirasi 
dalam perusahaan tersebut pada penyajian laporan keuangan, berupa overstatement pada akun penjualan dan piutang per 31 Desember 2003.

Tidak hanya pada KAP bahkan kasus yang menyangkut profesi auditor juga terjadi pada lembaga independen pemerintah, yaitu Badan Pemeriksa Keuangan Republik Indonesia (BPK-RI). Akhir bulan Mei 2017, masyarakat Indonesia dikejutkan dengan telah ditetapkannya salah satu pejabat BPK sebagai tersangka kasus suap terkait pemberian opini wajar tanpa pengecualian (WTP) terhadap laporan keuangan Kementerian Desa Pembangunan Daerah Tertinggal dan Transmigrasi (PDTT). Munculnya kasus "jual beli predikat WTP"” tersebut membuat keberadaaan profesi auditor diragukan dan kepercayaan publik menjadi terkikis. Kasus ini menyebabkan adanya expectation gap terhadap profesi auditor karena adanya kesenjangan antara harapan dan fakta yang terjadi. Hal ini tentu berdampak pada kualitas audit yang menurun akibat adanya kolusi dan kecurangan yang terjadi.

Kualitas audit yang baik pada prinsipnya dapat dicapai jika auditor menerapkan standar dan prinsip audit, bersikap tak memihak (independence), patuh kepada hukum, serta menaati kode etik profesi. De Angelo (1981) mengemukakan bahwa kualitas audit merupakan probabilitas (kemungkinan) dimana seorang auditor menemukan dan melaporkan tentang adanya suatu pelanggaran dalam sistem akuntansi kliennya.

Jasa profesional yang kompeten mensyaratkan pertimbangan yang cermat dalam menerapkan pengetahuan dan keahlian profesional untuk jasa yang diberikan. Untuk mampu mendapatkan pertimbangan secara cermat, auditor harus 
memiliki due professional care. Sikap Due professional care merupakan suatu sikap yang menuntut auditor untuk melaksanakan skeptisme profesional, yaitu suatu sikap auditor yang berpikir kritis terhadap bukti audit dengan tidak mudah percaya dan melakukan evaluasi terhadap bukti audit tersebut. Louwers dkk (1997) menyebutkan bahwa gagalnya audit dapat terjadi akibat rendahnya skeptisme auditor. Pernyataan ini sejalan dengan Singgih Bawono (2010) dan Febriyanti (2014) yang menemukan bahwa due professional care mempengaruhi kualitas audit. Namun, Zawitri (2009) dan Badjuri (2011) menyatakan bahwa meningkatnya due professional care auditor tidak berpengaruh terhadap kualitas audit yang dihasilkan. Akuntabilitas merupakan suatu dorongan secara psikologis bagi seseorang untuk mempertanggungjawabkan segala tindakannya kepada lingkungan. Dalam bidang profesi khususnya bagi profesi auditor dituntut untuk dapat mempunyai integritas yang tinggi, tanggung jawab profesional, mengutamakan kepentingan masyarakat, obyektif dalam bekerja, dan selalu mampu mengembangkan tingkat keahlian dan mutu jasa yang diberikan. Dengan kata lain, auditor bertanggung jawab atas tata kelola suatu entitas melalui pengawasan strategi dan kewajibannya terkait akuntabilitas, termasuk pengawasan atas proses pelaporan keuangan (Meidawati, 2001). Hasil yang sama ditunjukkan oleh Cholifa (2015) dan Amerthajaya (2016). Namun, Putri (2015) menunjukkan hasil bahwa akuntabilitas berpengaruh negatif terhadap kualitas audit.

Dalam melaksanakan audit, seorang auditor tidak hanya melibatkan kemampuannya dalam bekerja. Hal penting yang harus ia kuasai adalah mampu mengelola diri dalam membina hubungan dengan orang lain. Kecerdasan 
emosional, seperti yang dikemukakan Patton (1998:3) bahwa penggunaan emosi yang efektif akan dapat mencapai tujuan dalam membangun hubungan yang produktif dan meraih keberhasilan kerja. Pernyataan ini diperkuat oleh penelitian yang dilakukan oleh Amelia (2009) dan Malyani (2017) yang menunjukkan adanya pengaruh kecerdasan emosional terhadap kinerja auditor. Namun, Hakim dan Esfandari (2015) menyatakan bahwa kecerdasan emosional tidak berpengaruh terhadap kualitas audit. Jaya dkk. (2016) menunjukan hasil bahwa kecerdasan emosional berpengaruh negatif terhadap kualitas audit.

Pemaparan hasil penelitian pengaruh due professional care, akuntabilitas, dan kecerdasan emosional pada kualitas audit ditemukan hasil yang inkosisten atau masih kontroversi yang diduga karena adanya faktor lain yang mempengaruhi hubungan antara variabel bebas dengan variabel terikat. Secara konseptual dan hasil riset empiris, terdapat beberapa variabel yang diduga berperan memoderasi pengaruh due professional care, akuntabilitas, dan kecerdasan emosional pada kualitas audit, salah satu yang patut dipertimbangkan, yaitu reward.

Salah satu faktor yang dapat mendukung terciptanya kualitas audit yang lebih baik adalah pemberian reward bagi auditor. Henriansyah et al (2016) menyatakan bahwa pemberian motivasi berupa reward merupakan salah satu faktor yang dapat mempengaruhi kualitas audit. Pemberian reward berperan sebagai dorongan motivasi bagi auditor agar mampu menjalankan tugas dan fungsinya dengan optimal sehingga dapat menghasilkan kualitas audit yang lebih baik. Reward merupakan suatu ganjaran baik finansial maupun non finansial yang 
Putu Kemala Vidyantari dan I Dewa Gede Dharma Suputra. Pengaruh ...

memiliki kemampuan untuk dapat menyenangkan perasaan seorang pegawai dan memotivasinya, yang pada akhirnya pegawai akan melakukan pekerjaan dengan lebih cermat dan baik dimasa mendatang (Abdurrahman, 2014). Penelitian oleh Abdurrahman (2014), menghasilkan reward berpengaruh positif pada kinerja auditor.

Pemaparan hasil penelitian pengaruh due professional care, akuntabilitas, dan kecerdasan emosional pada kualitas audit ditemukan hasil yang inkosisten. Secara konseptual dan hasil riset empiris, terdapat beberapa variabel yang diduga berperan memoderasi pengaruh due professional care, akuntabilitas, dan kecerdasan emosional pada kualitas audit, salah satu yang patut dipertimbangkan, yaitu reward. Reward digunakan sebagai variabel pemoderasi karena mengacu pada pandangan bahwa reward sebagai pemotivasi kinerja seseorang menjadi lebih baik yang diikuti dengan capaian kualitas hasil kerja yang optimal dan sebagai bentuk pengakuan atas prestasi kerja. Ini menjadi dukungan reward dapat dijadikan sebagai penguat berbagai macam perilaku seseorang (Abdurrahman, 2014). Berdasarkan uraian tersebut, maka peneliti tertarik untuk mengambil topik penelitian dengan judul "Pengaruh Due Professional Care, Akuntabilitas, dan Kecerdasan Emosional pada Kualitas Audit dengan Reward sebagai Pemoderasi (Studi Empiris pada Kantor Akuntan Publik di Provinsi Bali)". Keistimewaan penelitian ini terletak pada dugaan bahwa reward memoderasi pengaruh due professional care, akuntabilitas, dan kecerdasan emosional pada kualitas audit. 
Berdasarkan latar belakang masalah yang telah dipaparkan, maka rumusan masalah dalam penelitian ini adalah sebagai berikut: 1) Apakah due professional care berpengaruh pada kualitas audit? 2) Apakah akuntabilitas berpengaruh pada kualitas audit? 3) Apakah kecerdasan emosional berpengaruh pada kualitas audit? 4) Apakah reward memoderasi pengaruh due professional care pada kualitas audit? 5) Apakah reward memoderasi pengaruh akuntabilitas pada kualitas audit? 6) Apakah reward memoderasi pengaruh kecerdasan emosional pada kualitas audit?

Berdasarkan rumusan masalah yang telah diuraikan, maka tujuan dari penelitian ini adalah sebagai berikut: 1) Untuk membuktikan secara empiris bagaimana reward memoderasi pengaruh due professional care, akuntabilitas, dan kecerdasan emosional pada kualitas audit. Secara teoritis penelitian ini dilakukan untuk dapat memberi tambahan wawasan mengenai reward memoderasi pengaruh due professional care, akuntabilitas, dan kecerdasan emosional pada kualitas audit. Penelitian ini juga dapat menjadi bukti dari teori keagenan dan teori harapan yang telah dikemukakan oleh para ahli.

Jensen-Meckling (1976) menjelaskan hubungan keagenan hubungan antara pemberi tugas (prinsipal) dan penerima tugas (agen). Dalam teori agensi perusahaan merupakan kumpulan kontrak (nexus of contract) antara pemilik sumber daya ekonomis (principal) dan manajer (agent) yang mengurus penggunaan dan pengendalian sumber daya tersebut. Hubungan keagenan ini menimbulkan agency problem yaitu terjadinya informasi asimetris dan timbulnya konflik kepentingan (conflict of interest) akibat ketidaksamaan tujuan, dimana 
Putu Kemala Vidyantari dan I Dewa Gede Dharma Suputra. Pengaruh ...

manajemen tidak selalu bertindak sesuai dengan kepentingan pemilik. Dalam upaya mengatasi masalah keagenan ini diperlukan suatu biaya keagenan (agency cost) yang terdiri dari : monitoring cost yang salah satu contoh biaya ini adalah biaya audit, bonding cost dan residual loss. Teori agensi mengemukakan bahwa peran auditor dianggap mampu menjadi penengah yang independen antara kepentingan pihak principal dan agen dalam mengelola keuangan entitas.

(Robbins, 2003:238) menyatakan bahwa teori harapan merupakan kekuatan kecenderungan seseorang untuk bertindak dengan cara tertentu tergantung dari kekuatan harapan bahwa tindakan itu akan diikuti oleh hasil tertentu dan tergantung pada daya tarik output itu bagi individu tersebut. Berdasarkan teori ini, hubungan antara kualitas kerja yang dihasilkan dan reward, adalah peran reward akan dapat meningkatkan kinerja dari sesorang yang pada akhirnya tentu akan meningkatkan level kualitas kerja dari seseorang sehingga akan terpuaskannya masing-masing sasaran organisasi ataupun individu. Abdurrahman (2014) menyatakan bahwa berdasarkan teori harapan, dapat diyakini bahwa reward menjadi sumber motivasi seseorang untuk menghidupkan harapan seseorang bahwa adanya kinerja yang baik dan kualitas kerja yang maksimal akan diikuti dengan penerimaan reward atas pengakuan terhadap prestasi kerja. Oleh karena itu reward dapat dijadikan sebagai pemotivasi pada tingkat perilaku dan prestasi seseorang.

Singgih Bawono (2010) meneukan bahwa kualitas audit dipengaruhi dengan arah positif oleh due professional care. Rizky dan Wirakusuma (2016) pun memperkuat pernyataan tersebut, mereka mengatakan bahwa tingginya due 
profesional care yang dimiliki auditor akan menghasilkan kualitas audit yang lebih baik. Penelitian oleh Krisna dan Budiartha (2017) juga mempertegas pernyataan tersebut. Berdasarkan uraian tersebut, maka dapat dirumuskan hipotesis sebagai berikut :

$\mathrm{H}_{1}$ : Due professional care berpengaruh positif pada kualitas audit

Akuntabilitas adalah suatu dorongan secara psikologi yang dapat membuat seseorang untuk mampu mempertanggungjawabkan tindakanyang telah mereka lakukan kepada lingkungannya atau orang lain (Meidawati, 2001). Badjuri (2011), menunjukkan penemuan hasil penelitian bahwa akuntabilitas berpengaruh positif pada kualitas audit. Hasil penelitian ini diperkuat oleh Ayu dan Dharma (2016) yang juga menyatakan jika akuntabilitas meningkat maka kualitas audit yang dihasilkan akan semakin baik. Berdasarkan uraian tersebut dapat dirumuskan hipotesis penelitian yaitu :

$\mathrm{H}_{2}$ : Akuntabilitas berpengaruh positif pada kualitas audit

Seorang auditor perlu memiliki kecerdasan emosional yang baik karena dalam lingkungan kerjanya auditor akan berinteraksi dengan berbagai jenis watak orang baik di dalam maupun di luar lingkungan kerja (Agus dan Yenni, 2016). Kecerdasan emosional dapat membantu auditor dalam melakukan pemeriksaan untuk mendeteksi kebenaran atas laporan keuangan yang disajikan klien (Swari dan Ramantha, 2013). Berdasarkan pernyataan di atas, maka hipotesis penelitian yang dapat dirumuskan yaitu:

$\mathrm{H}_{3}$ : Kecerdasan emosional berpengaruh positif pada kualitas audit 
Putu Kemala Vidyantari dan I Dewa Gede Dharma Suputra. Pengaruh ...

Djohar (2012) menyatakan bahwa pemberian reward akan lebih mendorong para auditor untuk berprestasi dalam bidangnya, dan untuk itu auditor harus dapat mengerjakan tugas-tugasnya dengan baik secara cermat dan saksama dan menghasilkan kualitas audit yang baik, yaitu dengan pencarian bukti-bukti yang relevan dan reliable. Pemberian reward bagi auditor akan memicu auditor untuk senantiasa selalu menerapkan due professional care dalam menjaga citra profesinya. Kualitas audit yang tinggi akan tercapai jika keinginan dan kebutuhan auditor yang menjadikan motivasi kerjanya dapat terpenuhi. Kompensasi dari organisasi berupa reward sesuai profesinya akan menimbulkan kualitas audit karena mereka merasa bahwa organisasi telah memperhatikan kebutuhan dan pengharapan kerja mereka (Hanjani dan Rahardja, 2014). Berdasarkan uraian tersebut dapat dirumuskan hipotesis penelitian:

$\mathrm{H}_{4}$ : Reward memperkuat pengaruh due professional care auditor pada kualitas audit

Auditor dituntut untuk menjaga kepercayaan publik dengan cara menjaga dan mempertahankan akuntabilitasnya. Dalam mempertanggung jawabkan tindakannya kepada lingkungan baik itu dalam hubungan vertikal dan horizontal menuntut auditor melakukan usaha audit yang tinggi. Usaha audit yang tinggi membutuhkan usaha daya pikir dan motivasi dalam bekerja yang tinggi yang pada akhirnya akan menghasilkan audit judgment yang tepat. Semakin luasnya lingkup tanggungjawab pekerjaan yang dimiliki auditor cenderung membutuhkan usaha audit yang tinggi. Sebuah reward yang dapat memacu dan memotivasi auditor untuk dapat melakukan usaha audit yang lebih tinggi sehingga mampu 
menghasilkan kualitas audit yang baik. Berdasarkan uraian tersebut dapat dirumuskan hipotesis penelitian yaitu :

$\mathrm{H}_{5}$ : Reward memperkuat pengaruh akuntabilitas pada kualitas audit.

Goleman (2003), menyatakan semakin kompleksnya suatu pekerjaan yang diemban seseorang maka semakin membutuhkan kecerdasan emosional pekerja tersebut. Tanpa kecerdasan emosional, seseorang tidak akan mampu menggunakan kemampuan kognitif mereka sesuai dengan potensi yang maksimum. Berdasarkan pernyataan di atas, maka hipotesis penelitian yang dapat dirumuskan yaitu:

$\mathrm{H}_{6}$ : Reward memperkuat pengaruh kecerdasan emosional pada kualitas audit.

\section{METODE PENELITIAN}

Penelitian ini merupakan penelitian kuantitatif dengan jenis asosiatif. Lokasi penelitian yang dilakukan yaitu di KAP Provinsi Bali yang menjadi anggota Institut Akuntan Publik Indonesia (IAPI) serta terdaftar dalam direktori Kantor Akuntan Publik Indonesia. Berikut ini disajikan Tabel 1 merupakan rincian KAP dan alamat. Jenis data yang digunakan dalam penelitian ini adalah data kuantitatif (jumlah auditor yang menjadi responden) dan kualitatif (gambaran umum dan nama KAP). Sumber data yang diperoleh yaitu dari data primer (dari kuesioner yang diisi oleh responden) dan data sekunder (jurnal ilmiah, buku, KAP yang terdaftar dalam IAPI). 
Tabel 1.

Daftar Nama KAP di Provinsi Bali, 2017

\begin{tabular}{|c|c|c|}
\hline No & Nama Kantor Akuntan Publik & $\begin{array}{r}\text { Alamat Kantor } \\
\text { Akuntan Publik }\end{array}$ \\
\hline 1. & KAP I Wayan Ramantha & Jl. Rampai No. IA Lt. 3, Denpasar, Bali. Telp:(0361) 263643 \\
\hline 2. & $\begin{array}{l}\text { KAP Johan Malonda Mustika \& Rekan } \\
\text { (Cab) }\end{array}$ & $\begin{array}{l}\text { Jl. Muding Indah I/5, Kerobokan Kuta Utara, Badung, Bali. } \\
\text { Telp:(0361) } 434884\end{array}$ \\
\hline 3. & KAP K. Gunarsa & $\begin{array}{l}\text { Jl. Tukad Banyusari Gg. II No.5, Denpasar, Bali. Telp:(0361) } \\
225580\end{array}$ \\
\hline 4. & KAP Drs. Ketut Budiartha, M.Si & $\begin{array}{l}\text { Jl. Gunung Agung Perum Padang Pesona, Graha Adi A6, Denpasar, } \\
\text { Bali. Telp:(0361) } 8849168\end{array}$ \\
\hline 5. & $\begin{array}{l}\text { KAP Drs. Sri Marmo Djogosarkoro \& } \\
\text { Rekan }\end{array}$ & $\begin{array}{l}\text { Jl. Gunung Muria Blok VE No.4, Monang Maning, Denpasar, Bali. } \\
\text { Telp:(0361) 480033, 480032, 482422 }\end{array}$ \\
\hline 6. & KAP Drs. Wayan Sunasdyana & $\begin{array}{l}\text { Jl. Pura Demak I Gang Buntu No.89, Denpasar, Bali. Telp:(0361) } \\
\text { 7422329, } 8518989\end{array}$ \\
\hline 7. & KAP Drs. Ketut Muliartha R.M. \& Rekan & $\begin{array}{l}\text { Jl. Drupadi No.25, Denpasar, Bali. Telp:(0361) 248110, } 265227 \\
\text { Jl. Cargo Indah III A Perum. Melang Hill No. 1, Ubung, Denpasar }\end{array}$ \\
\hline 8. & KAP Arnaya dan Darmayasa & $\begin{array}{l}\text { Utara } \\
\text { Telp: (0361) } 4714308\end{array}$ \\
\hline 9. & KAP Budhananda Muni Dewi & $\begin{array}{l}\text { Jl. Tukad Irawadi No. 18A, Lantai } 2 \text { \& } 3 \text { Kelurahan Panjer, } \\
\text { Kecamatan Denpasar Selatan } \\
\text { Telp: (0361) } 245644\end{array}$ \\
\hline
\end{tabular}

Populasi yang digunakan pada penelitian ini tersaji dalam tabel berikut :

Tabel 2.

Jumlah Auditor pada Kantor Akuntan Publik di Bali, 2017

\begin{tabular}{lll}
\hline No & Nama Kantor Akuntan Publik & $\begin{array}{l}\text { Jumlah Auditor } \\
\text { (Orang) }\end{array}$ \\
\hline 1. & KAP I Wayan Ramantha & 10 \\
2. & KAP Johan Malonda Mustika \& Rekan (Cab) & 5 \\
3. & KAP K. Gunarsa & 3 \\
4. & KAP Drs. Ketut Budiartha, M.Si & 6 \\
5. & KAP Drs. Sri Marmo Djogosarkono \& Rekan & 16 \\
6. & KAP Drs. Wayan Sunasdyana & 6 \\
7. & KAP Drs. Ketut Muliartha R.M. \& Rekan & 10 \\
8. & KAP Arnaya dan Darmayasa & 10 \\
9. & KAP Budhananda Munidewi & 6 \\
Total & & $\mathbf{7 2}$ \\
\hline
\end{tabular}

Menentukan sampel penelitian metode yang digunakan yaitu non probability sampling teknik sampling jenuh, dari metode tersebut maka seluruh populasi (72 auditor) akan menjadi sampel. 
Penelitian ini menggunakan metode pengumpulan data primer yaitu melalui survey, berupa kuesioner mengenai due professional care, akuntabilitas, kecerdasan emosional, reward, dan kualitas audit dengan daftar pernyataan yang akan diberikan kepada responden. Hasil dari kuesioner kemudian diukur dengan skala Likert yang dinilai dengan skala 5 poin (5 adalah poin tertinggi dan 1 adalah poin terendah). Data pada penelitian ini dianalisis dengan menggunakan teknik analisis data yaitu dengan uji validitas, uji reliabilitas, asumsi klasik (uji normalitas, uji multikolinearitas, uji heteroskedasitas), analisis regresi moderasi/ moderated regression analysis (MRA), koefisien determinasi $\left(\mathrm{R}^{2}\right)$, uji kelayakan model (uji f), dan uji hipotesis (uji t). Model regresi dalam penelitian ini ditunjukkan dengan persamaan sebagai berikut:

$\mathrm{Y}=\alpha+\beta_{1} \mathrm{X}_{1}+\beta_{2} \mathrm{X}_{2}+\beta_{3} \mathrm{X}_{3}+\mu$

$Y=\alpha+\beta_{1} X_{1}+\beta_{2} X_{2}+\beta_{3} X_{3}+\beta_{4} X_{1} X_{4}+\beta_{5} X_{2} X_{4}+\beta_{6} X_{3} X_{4}+\mu$

Keterangan:

$\mathrm{Y}=$ Kualitas audit; $\alpha=$ Konstanta; $\beta_{1}-\beta_{6}=$ Koefisien; $\mathrm{X}_{1}=$ Due Professional Care; $\mathrm{X}_{2}=$ Akuntabilitas; $\mathrm{X}_{3}=$ Kecerdasan Emosional; $\mathrm{X}_{4}=$ Reward ; $\mu=$ Standard Error

\section{HASIL DAN PEMBAHASAN}

Sesuai dengan metode penentuan sampel yang telah digunakan yaitu non probability sampling dengan teknik sampling jenuh maka seluruh populasi menjadi sampel. Kuesioner yang telah disebarkan sejumlah 56 dan responden yang mengisi sebanyak 47 yang dapat dilihat pada tabel berikut. 
Tabel 3.

Jumlah Penyebaran dan Pengembalian Kuesioner

\begin{tabular}{|c|c|c|c|}
\hline No & Nama Kantor Akuntan Publik & $\begin{array}{l}\text { Jumlah } \\
\text { Kuesioner } \\
\text { Tersebar }\end{array}$ & $\begin{array}{l}\text { Jumlah } \\
\text { Kuesioner } \\
\text { Kembali }\end{array}$ \\
\hline 1 & KAP I Wayan Ramantha & 10 & 8 \\
\hline 2 & KAP Johan Malonda Mustika \& Rekan (Cab) & 5 & 4 \\
\hline 3 & KAP K. Gunarsa & 3 & 3 \\
\hline 4 & KAP Drs. Ketut Budiartha, M.Si & 6 & 6 \\
\hline 5 & KAP Drs. Sri Marmo Djogosarkono \& Rekan & - & - \\
\hline 6 & KAP Drs. Wayan Sunasdyana & 6 & 6 \\
\hline 7 & KAP Drs. Ketut Muliartha R.M. \& Rekan & 10 & 10 \\
\hline 8 & KAP Arnaya dan Darmayasa & 10 & 4 \\
\hline 9 & KAP Budhananda Munidewi & 6 & 6 \\
\hline Tota & & 56 & 47 \\
\hline
\end{tabular}

Sumber: Data diolah, 2017

Pada tabel 3 total auditor yang bekerja pada 9 KAP sebanyak 72 orang dan total kuesioner yang disebar seharusnya sebanyak 72 eksemplar. Tabel 4.1 menunjukkan jumlah kuesioner yang disebar sebanyak 47 eksemplar. Hal ini disebabkan oleh KAP Drs. Sri Marmo Djogosarkono \& Rekan tidak menerima pengisian kuesioner. KAP Johan Malonda Mustika \& Rekan (Cab) hanya menerima 4 kuesioner dari 5 jumlah auditor yang ada, begitu pula pada KAP Arnaya dan Darmayasa hanya mengisi 4 kuesioner dari 10, serta dari KAP Ramantha mengisi 8 dari 10 kuesioner. Berdasarkan seluruh jumlah kuesioner yang disebarkan, kuesioner yang kembali sebanyak 47 eksemplar. 
Tabel 4.

Data Pengambilan dan Pengembalian Kuesioner

\begin{tabular}{ll}
\hline Uraian & Jumlah Kuesioner \\
\hline Total kuesioner yang disebar & 56 \\
Kuesioner tidak terisi & 9 \\
Kuesioner dikembalikan dan terisi & 47 \\
Kuesioner yang digunakan dalam analisis & 47 \\
Tingkat pengembalian/ Response Rate & $83,9 \%$ \\
Useable Response Rate & $83,9 \%$ \\
\hline
\end{tabular}

Sumber: Data Primer (Data Diolah, 2017)

Pada tabel di atas jumlah kuesioner yang dikembalikan sejumlah 47 eksemplar dan seluruhnya dapat digunakan. Data karakteristik profil responden dengan jumlah 47 diuraikan sebagai berikut: $51 \%$ responden adalah pria dengan jumlah 24 orang dan sisanya adalah wanita (23 orang) dengan jumlah persentase 49\%. Mayoritas responden berusia kurang dari 26 tahun (39 orang yaitu 82 persen), antara 26 sampai 35 tahun sebanyak 8\% (4 orang), 36 sampai 45 tahun sebanyak 6\% (3 orang), dan hanya satu orang (4\%) yang berusia lebih dari 45 tahun. Responden didominasi oleh auditor yang telah memiliki masa kerja lebih dari sama dengan 1 tahun (79\% atau 37 orang) dan sisanya 10 orang (21\%) kurang dari 1 tahun. Responden mayoritas memiliki jenjang pendidikan S1 (76\% yaitu 36 orang), kemudian S2 18\% (8 orang), dan 6\% (3 orang) dengan jenjang pendidikan D3. Jabatan digunakan untuk mengetahui kedudukan responden pada Kantor Akuntan Publik. Responden dengan status auditor junior adalah yang paling mendominasi sebesar 73\% (34 orang), 12 auditor senior (25\%), dan 1 orang ( 2 persen) responden sebagai partner.

Uji validitas dilihat dari nilai pearson correlation yang memiliki nilai positif dan lebih dari 0,30 menunjukkan bahwa instrumen penelitian yang digunakan terbukti valid (Sugiyono, 2013:189). Tabel 4 menyajikan hasil uji validitas instrumen penelitian. 
Tabel 5.

Hasil Uji Validitas

\begin{tabular}{lccc}
\hline \multicolumn{1}{c}{ Variabel Penelitian } & Indikator & $\begin{array}{c}\text { Pearson } \\
\text { Correlation }\end{array}$ & Keterangan \\
\hline Due Professional Care & $\mathrm{X}_{1.1}-\mathrm{X}_{1.7}$ & $0,425-0,607$ & Valid \\
Akuntabilitas & $\mathrm{X}_{2.1}-\mathrm{X}_{2.6}$ & $0,674-0,868$ & Valid \\
Kecerdasan Emosional & $\mathrm{X}_{3.1}-\mathrm{X}_{3.11}$ & $0,548-0,815$ & Valid \\
Reward & $\mathrm{X}_{4.1}-\mathrm{X}_{4.5}$ & $0,614-0,747$ & Valid \\
Kualitas Audit & $\mathrm{Y}_{1}-\mathrm{Y}_{7}$ & $0,619-0,924$ & Valid \\
\hline
\end{tabular}

Sumber: Data Primer (Data Diolah, 2017),

Pada Tabel 5 terlihat variabel kualitas audit, due professional care, akuntabilitas, kecerdasan emosional, dan reward dengan pearson correlation di atas 0,3 yang berarti pernyataan dalam kuesioner telah valid.

Uji reliabilitas dilakukan dengan tujuan untuk melihat keandalan alat ukur yang dilihat dari koefisien Cronbach's Alpha suatu instrumen, jika di atas 0,60 maka instrumen telah lulus uji dan dikatakan reliabel (Ghozali, 2016:48). Berikut ini disajikan Tabel 4.5 hasil uji reliabilitas instrumen penelitian.

Tabel 6.

Hasil Uji Reliabilitas

\begin{tabular}{lll}
\hline Variabel & Cronbach's Alpha & Keterangan \\
\hline Kualitas Audit $(\mathrm{Y})$ & 0,885 & Reliabel \\
Due Professional Care $\left(\mathrm{X}_{1}\right)$ & 0,706 & Reliabel \\
Akuntabilitas $\left(\mathrm{X}_{2}\right)$ & 0,853 & Reliabel \\
Kecerdasar Emosional $\left(\mathrm{X}_{3}\right)$ & 0,912 & Reliabel \\
Reward $\left(\mathrm{X}_{4}\right)$ & 0,781 & Reliabel \\
\hline
\end{tabular}

Sumber: Data diolah, 2017

Berdasarkan Tabel 6 terlihat bahwa kelima instrumen penelitian memiliki koefisien Cronbach's Alpha lebih besar dari 0,60 sehingga pernyataan dalam kuesioner tersebut reliabel.

Uji normalitas dilakukan untuk menguji apakah dalam sebuah model regresi telah berdistribusi normal atau tidak. Uji normalitas pada data penelitian ini dilakukan dengan metode Kolmogorov-Smirnov, data telah berdistribusi 
normal jika nilai Asymp. Sig (2-tailed) melebihi level of significant yang dipakai yaitu 0,05 . Berikut ini merupakan hasil uji normalitas

Tabel 7.

Hasil Uji Normalitas

\begin{tabular}{ll}
\hline Kolmogorov-Smirnov & Unstandardized Residual \\
\hline N & 47 \\
Asymp.Sig.(2-tailed) & 0,491 \\
\hline \multicolumn{2}{c}{ Sumber: Data Primer (Data Diolah, 2017) }
\end{tabular}

Tabel di atas menunjukkan nilai signifikansi 0,491 > 0,05 yang berarti model regresi dalam penelitian ini berdistribusi normal.

Uji heteroskedastisitas dianalisis melalui metode Glejser yang dilakukan dengan melakukan regresi pada nilai absolute residual sebagai variabel terikat dengan variabel bebas. Model regresi bebas dari heteroskedastisitas jika nilai signifikansi t masing-masing variabel bebas melebihi 0,05. Berikut hasil uji heteroskedastisitas.

Tabel 8.

Hasil Uji Heteroskedastisitas

\begin{tabular}{llll}
\hline Model & Variabel & Signifikansi & Keterangan \\
\hline 1 & X1 & 0.273 & Bebas Heteroskedastisitas \\
& X2 & 0.065 & Bebas Heteroskedastisitas \\
& X3 & 0.203 & Bebas Heteroskedastisitas \\
& X4 & 0.421 & Bebas Heteroskedastisitas \\
& X1_X4 & 0.263 & Bebas Heteroskedastisitas \\
& X2_X4 & 0.074 & Bebas Heteroskedastisitas \\
& X3_X4 & 0.091 & Bebas Heteroskedastisitas \\
\hline
\end{tabular}

Sumber: Data diolah, 2017

Tabel 8 menunjukkan seluruh variabel independen bebas dari heteroskedastisitas

Uji multikolinearitas adalah pengujian yang dilakukan untuk mengetahui apakah pada model regresi ditemukan adanya korelasi antar variabel bebas. Jika nilai tolerance lebih besar dari $10 \%$ atau VIF kurang dari 10 maka dapat 
Putu Kemala Vidyantari dan I Dewa Gede Dharma Suputra. Pengaruh ...

dikatakan model telah bebas dari masalah multikolinearitas. Hasil uji multikolonearitas penelitian disajikan pada Table 4.8 sebagai berikut.

Tabel 9.

Hasil Uji Multikolinearitas

\begin{tabular}{lllll}
\hline Model & Variabel & Tolerance & VIF & Keterangan \\
\hline 1 & X1 & 0.204 & 6.94 & Bebas Multikolinearitas \\
& X2 & 0.203 & 0.948 & Bebas Multikolinearitas \\
& X3 & 0.182 & 3.709 & Bebas Multikolinearitas \\
& X4 & 0.204 & 2.893 & Bebas Multikolinearitas \\
& X1_X4 & 0.121 & 1.594 & Bebas Multikolinearitas \\
& X2_X4 & 0.251 & 7.558 & Bebas Multikolinearitas \\
& X3_X4 & 0.301 & 2.126 & Bebas Multikolinearitas \\
\hline
\end{tabular}

Sumber: Data diolah, 2017

Pada Tabel 9 nilai tolerance disetiap variabel lebih besar dari 10\%, dan nilai VIF kurang dari 10 yang artinya model regresi bebas dari masalah multikolinearitas.

Analisis regresi linier berganda digunakan untuk menguji pengaruh variabel independen pada variabel dependen. Berdasarkan hasil olah data dengan bantuan SPSS, maka didapatkan hasil seperti di bawah ini:

Tabel 10.

Hasil Analisis Regresi Linear Berganda

\begin{tabular}{|c|c|c|c|c|c|c|c|}
\hline \multirow[t]{2}{*}{ Model } & \multirow[t]{2}{*}{ Variabel } & \multicolumn{2}{|c|}{$\begin{array}{l}\text { Unstandardized } \\
\text { Coefficients }\end{array}$} & \multirow{2}{*}{$\begin{array}{l}\text { Standardized } \\
\text { Coefficients } \\
\text { Beta } \\
\end{array}$} & \multirow[t]{2}{*}{$\mathbf{t}$} & \multirow[t]{2}{*}{ Sig. } & \multirow[t]{2}{*}{ Hasil Uji } \\
\hline & & B & Std. Error & & & & \\
\hline \multirow[t]{4}{*}{1} & (Constant) & -2.243 & 2.246 & & -0.999 & 0.323 & \\
\hline & $\mathrm{X} 1$ & 0.242 & 0.086 & 0.177 & 2.815 & 0.007 & Diterima \\
\hline & $\mathrm{X} 2$ & 0.71 & 0.11 & 0.634 & 6.426 & 0 & Diterima \\
\hline & $\mathrm{X} 3$ & 0.164 & 0.072 & 0.235 & 2.266 & 0.029 & Diterima \\
\hline \multicolumn{2}{|c|}{ Adjusted R Square } & 0.86 & & & & & \\
\hline \multicolumn{2}{|c|}{ F Hitung } & 98.58 & & & & & \\
\hline \multicolumn{2}{|c|}{ Sig. F Hitung } & 0.00 & & & & & \\
\hline
\end{tabular}

Berdasarkan Tabel 10 dapat disusun persamaan regresi sebagai berikut:

$Y=-2,243+0,242 X_{1}+0,710 X_{2}+0,164 X_{3}+\mu$

Uji MRA adalah teknik analisis data yang dilakukan untuk mengetahui pengaruh variabel bebas pada variabel terikat dan kemampuan variabel 
pemoderasi dalam memoderasi pengaruh variabel independen pada variabel dependen. Menurut hasil olah data dengan bantuan SPSS, maka diperlah hasil sebagai berikut:

Tabel 11.

Hasil Analisis Regresi dengan Variabel Moderasi

\begin{tabular}{|c|c|c|c|c|c|c|c|}
\hline \multirow{2}{*}{ Model } & \multirow{2}{*}{ Variabel } & \multicolumn{2}{|c|}{$\begin{array}{l}\text { Unstandardized } \\
\text { Coefficients }\end{array}$} & \multirow[t]{2}{*}{$\begin{array}{l}\text { Standardized } \\
\text { Coefficients }\end{array}$} & \multirow{2}{*}{$\mathbf{T}$} & \multirow{2}{*}{ Sig. } & \multirow{2}{*}{$\begin{array}{l}\text { Hasil } \\
\text { Uji }\end{array}$} \\
\hline & & B & $\begin{array}{l}\text { Std. } \\
\text { Error }\end{array}$ & & & & \\
\hline \multirow[t]{8}{*}{1} & (Constant) & -10.039 & 26.288 & & -0.382 & 0.705 & \\
\hline & $\mathrm{X} 1$ & 0.118 & 1.233 & 0.086 & 1.095 & 0.024 & \\
\hline & $\mathrm{X} 2$ & 0.206 & 1.212 & 0.077 & 1.005 & 0.036 & \\
\hline & $\mathrm{X} 3$ & 0.883 & 0.923 & 1.265 & 2.956 & 0.045 & \\
\hline & $\mathrm{X} 4$ & 0.501 & 1.344 & 0.326 & 3.372 & 0.012 & \\
\hline & X1_X4 & 0.215 & 0.058 & 0.425 & 2.264 & 0.044 & Diterima \\
\hline & $\mathrm{X} 2 \_\mathrm{X} 4$ & 0.333 & 0.059 & 0.95 & 2.557 & 0.03 & Diterima \\
\hline & $\mathrm{X} 3 \_\mathrm{X} 4$ & 0.435 & 0.045 & 1.722 & 3.78 & 0.04 & Diterima \\
\hline \multicolumn{2}{|c|}{ Adjusted R Square } & \multicolumn{2}{|c|}{0.854} & & & & \\
\hline \multicolumn{2}{|c|}{ F Hitung } & \multicolumn{2}{|c|}{39.582} & & & & \\
\hline \multicolumn{2}{|c|}{ Sig. F Hitung } & \multicolumn{2}{|c|}{0.000} & & & & \\
\hline
\end{tabular}

Pada Tabel 11 persamaan regresi dapat disusun sebagai berikut:

$Y=-10.039+0,118 X_{1}+0,206 X_{2}+0,883 X_{3}+0,501 X_{4}+0,215 X_{1} X_{4}+0,333$

$X_{2} X_{4}+0,435 X_{3} X_{4}+\mu$

Berdasarkan persamaan di atas, dapat dijelaskan hal-hal yaitu: 1) Nilai koefisien $\beta_{1}=0,118$. 2) Hal ini bermakna due professional care semakin meningkat, maka kualitas audit akan mengalami peningkatan senilai 0,118 satuan. 3) Nilai koefisien $\beta_{2}=0,206$. Hal ini bermakna akuntabilitas semakin meningkat, maka kualitas audit akan mengalami peningkatan senilai 0,206 satuan. 4) Nilai koefisien $\beta_{3}=0,883$. Hal ini berarti jika kecerdasan emosional auditor meningkat, maka kualitas audit pun akan meningkat senilai 0,883 satuan. 5) Nilai koefisien $\beta_{4}=0,501$. Hal ini bermakna reward semakin meningkat, maka 
kualitas auditpun akan semakin meningkat senilai 0,501 satuan. 6) Nilai koefisien koefisien $\beta_{5}=0,215$. Hal ini bermakna bahwa setiap interaksi due proffesional care dengan reward semakin meningkat, maka kualitas auditpun akan semakin meningkat senilai 0,215 satuan. 7) Nilai koefisien koefisien $\beta_{6}=0,333$. Hal ini bermakna bahwa setiap interaksi akuntabilitas dengan reward semakin meningkat, maka kualitas auditpun akan semakin meningkat senilai 0,333 satuan. 8) Nilai koefisien koefisien $\beta_{7}=0,435$. Hal ini bermakna bahwa setiap interaksi kecerdasan emosional dengan reward semakin meningkat, maka kualitas audit akan semakin meningkat senilai 0,435 satuan.

Uji kelayakan model atau uji F pada Tabel 4.10, menyatakan variabel bebas berpengaruh serempak (simultan) pada variabel terikat. Nilai Signifikansi F 0,000 $<0,05$ bermakna model penelitian ini dikatakan layak dan seluruh variabel bebas (due professional care, akuntabilitas, kecerdasan emosional dan reward) dapat memprediksi fenomena kualitas audit di KAPProvinsi Bali. Koefisien determinasi $\left(\mathrm{R}^{2}\right)$ pada Tabel 4.10 dilihat dari nilai adjusted $R^{2}$ yaitu 0,854 yang artinya bahwa $85,4 \%$ variasi kualitas audit ini dipengaruhi oleh variasi due professional care $\left(\mathrm{X}_{1}\right)$, akuntabilitas $\left(\mathrm{X}_{2}\right)$ kecerdasan emosional $\left(\mathrm{X}_{3}\right)$, reward $\left(\mathrm{X}_{4}\right)$ dan $14,6 \%$ dipengaruhi faktor lain di luar model.

Uji t dapat menjelaskan pengaruh setiap variabel independen secara parsial pada variabel dependen dan dapat menunjukkan mampu tidaknya variabel pemoderasi mempengaruhi variabel independen pada variabel dependen. Menurut Tabel 4.10, hasil uji t diartikan sebagai berikut: 1)Variabel due professional care $\left(\mathrm{X}_{1}\right)$ memiliki tingkat signifikansi t senilai $0,024<0,05$. Hal ini berarti due 
professional care berpengaruh positif dan signifikan pada kualitas audit. 2)Variabel akuntabilitas $\left(X_{2}\right)$ memiliki tingkat signifikansi t senilai $0,036<0,05$. Hal ini berarti akuntabilitas berpengaruh positif dan signifikan pada kualitas audit. 3)Variabel kecerdasan emosional $\left(X_{3}\right)$ memiliki tingkat signifikansi t senilai 0,045 $<0,05$. Hal ini berarti kecerdasan emosional berpengaruh positif dan signifikan pada kualitas audit. 4)Variabel reward $\left(\mathrm{X}_{4}\right)$ memiliki tingkat signifikansi t sebesar $0,012<0,05$. Hal ini memiliki arti reward memiliki pengaruh positif signifikan pada kualitas audit. 5)Variabel interaksi due professional care dengan reward memiliki tingkat signifikansi t sebesar $0,044<0,05$. Hal ini berarti reward $\left(\mathrm{X}_{4}\right)$ dapat memoderasi pengaruh due professional care pada kualitas audit. 6)Variabel interaksi akuntabilitas dengan reward memiliki tingkat signifikansi t senilai 0,03 $<0,05$. Hal ini reward $\left(\mathrm{X}_{4}\right)$ mampu memoderasi pengaruh akuntabilitas audit pada kualitas audit. 7)Variabel interaksi kecerdasan emosional dengan reward memiliki tingkat signifikansi t senilai $0,04<0,05$. Hal ini berarti reward $\left(\mathrm{X}_{4}\right)$ mampu memoderasi pengaruh kecerdasan emosional pada kualitas audit.

Pada uji parsial yang ditemukan adanya pengaruh positif due professional care pada kualitas audit dan juga menerima hipotesis $\mathrm{H}_{1}$ yang menyatakan due professional care berpengaruh positif dan signifikan pada kualitas audit. Semakin tinggi due professional care yang dimiliki oleh seorang auditor mengakibatkan semakin tingginya kualitas audit yang dihasilkan. Karakteristik data responden menunjukkan bahwa 79\% auditor di KAP Provinsi Bali memiliki masa kerja lebih dari 1 tahun yang artinya telah memiliki pengalaman kerja dan kemampuan profesional. Sikap yang cermat dan seksama dalam kemahiran professional 
membantu auditor memperoleh rasa yakin yang memadai bagi dirinya untuk bisa memberikan pernyataan bahwa laporan keuangan sudah terbebas dari salah saji material, entah itu diakibatkan dari sebuah kesalahan yang tidak disengaja maupun sebuah kecurangan yang sengaja dilakukan (Darmawan dan Astika, 2017). Berdasarkan penemuan tersebut, dapat dikatakan bahwa due professional care berperan dalam menentukan suatu kualitas audit yang dihasilkan oleh auditor di KAP Provinsi Bali.

Pada uji parsial yang ditemukan adanya pengaruh positif akuntabilitas pada kualitas audit dan juga menerima hipotesis $\mathrm{H}_{2}$ yang menyatakan akuntabilitas berpengaruh positif dan signifikan pada kualitas audit. Semakin tinggi akuntabilitas seorang auditor berdampak pada semakin tingginya kualitas audit yang dihasilkan. Dalam konteks profesi auditor akuntabilitas menuntutnya untuk berkomitmen dalam menjaga kerahasiaan informasi, hal ini dimulai pada dari ketika auditor telah memperoleh data-data yang diberikan oleh klien sampai dengan hasil temuan yang diperoleh pada saat pemeriksaan. Apabila seorang akuntan menyadari besarnya peran profesi auditor bagi masyarakat, maka ia akan memiliki keyakinan untuk melakukan pekerjaan dengan sebaik- baiknya (Singgih dan Bawono, 2010). Akhirnya, hal ini tentu akan meningkatkan kualitas audit yang dihasilkan selama proses pemeriksaan. Penemuan ini dapat menyatakan bahwa akuntabilitas berperan dalam menentukan suatu kualitas audit yang dihasilkan oleh auditor di KAP Provinsi Bali.

Pada uji parsial yang ditemukan adanya pengaruh positif kecerdasan emosional pada kualitas audit dan juga menerima hipotesis $\mathrm{H}_{3}$ yang menyatakan 
kecerdasan emosional berpengaruh positif dan signifikan pada kualitas audit. Semakin tinggi kecerdasan emoisonal yang dimiliki oleh seorang auditor mengakibatkan semakin tingginya kualitas audit yang dihasilkan. Auditor merupakan profesi yang bekerja dengan melibatkan suatu hubungan dengan orang lain, baik itu hubungannya dalam rekan kerja bersama tim, dengan atasan, dan tentu dengan klien. Penemuan ini dapat menyatakan kecerdasan emosional berperan dalam menentukan suatu kualitas audit yang dihasilkan oleh auditor di KAP Provinsi Bali.

Hasil uji moderasi menunjukkan bahwa reward mampu memoderasi pengaruh due professional care pada kualitas audit. Hasil ini menunjukkan bahwa reward memperkuat pengaruh due professional care pada kualitas audit. Hasil ini menerima hipotesis $\mathrm{H}_{4}$. Setelah dilakukan pengujian, hasil penelitian menunjukkan bahwa tingkat signifikansi nilai t sebesar 0,044. Nilai koefisien regresi sebesar 0,215 menunjukkan reward sebagai variabel pemoderasi sifatnya memperkuat hubungan antara skeptisisme profesional pada kinerja auditor.

Fenomena yang ditunjukkan oleh penelitian ini mengindikasikan bahwa semakin tinggi due professional care yang dimiliki seorang auditor dapat meningkatkan kualitas audit yang dihasikan. Pemberian reward akan lebih memotivasi auditor untuk berprestasi dalam bidangnya, yaitu dengan mengerjakan tugas-tugasnya dengan baik salah satunya adalah pencarian bukti-bukti yang relevan sehingga menyebabkan kualitas audit yang dihasilkan semakin baik. Selain itu, dengan diberikannya reward bagi auditor, maka auditor akan senantiasa selalu menerapkan skeptisisme profesional (cermat dan seksama) untuk 
menjaga citra profesinya dan menjaga reputasi dari KAP tempat auditor tersebut bekerja. Responden pada penelitian ini $73 \%$ adalah auditor junior yang merupakan staf pelaksana langsung dan bertanggung jawab atas pekerjaan lapangan, yang tentunya kemahiran profesional yang cermat dan seksama sangat dibutuhkan sehingga dengan penerimaan reward tentu dapat memotivasi mereka untuk bekerja lebih baik lagi.

Pada uji moderasi menunjukkan hasil reward memiliki kemampuan dalam memoderasi pengaruh due professional care pada kualitas audit. Hasil ini menunjukkan bahwa reward memperkuat pengaruh due professional care pada kualitas audit. Setelah dilakukan pengujian, hasil penelitian menunjukkan bahwa tingkat signifikansi nilai $\mathrm{t}$ sebesar 0,044 . Nilai koefisien regresi sebesar 0,215 menunjukkan reward sebagai variabel pemoderasi sifatnya memperkuat hubungan antara skeptisisme profesional pada kinerja auditor. Hasil ini menerima hipotesis $\mathrm{H}_{4}$. Fenomena yang ditunjukkan oleh penelitian ini mengindikasikan bahwa semakin tinggi due professional care yang dimiliki seorang auditor dapat meningkatkan kualitas audit yang dihasikan. Pemberian reward akan lebih memotivasi auditor untuk berprestasi dalam bidangnya, yaitu dengan mengerjakan tugas-tugasnya dengan baik salah satunya adalah pencarian bukti-bukti yang relevan sehingga menyebabkan kualitas audit yang dihasilkan semakin baik. Selain itu, dengan diberikannya reward bagi auditor, maka auditor akan senantiasa selalu menerapkan skeptisisme profesional (cermat dan seksama) untuk menjaga citra profesinya dan menjaga reputasi dari KAP tempat auditor tersebut bekerja. Responden pada penelitian ini $73 \%$ adalah auditor junior yang merupakan 
staf pelaksana langsung dan bertanggung jawab atas pekerjaan lapangan, yang tentunya kemahiran profesional yang cermat dan seksama sangat dibutuhkan sehingga dengan penerimaan reward tentu dapat memotivasi mereka untuk bekerja lebih baik lagi. Penemuan ini dapat menjelaskan bahwa reward memperkuat hubungan due prfessional care pada kualitas audit yang dihasilkan oleh auditor di KAP Provinsi Bali.

Pada uji moderasi menunjukkan hasil reward memiliki kemampuan dalam memoderasi pengaruh akuntabilitas pada kualitas audit. Hasil ini menunjukkan bahwa reward memperkuat pengaruh akuntabilitas pada kualitas audit, dengan tingkat signifikansi nilai t sebesar 0,03 dan nilai koefisien regresi sebesar 0,333 menunjukkan reward sebagai variabel pemoderasi sifatnya memperkuat hubungan antara akuntabilitas pada kualitas audit. Hasil ini menerima hipotesis $\mathrm{H}_{5}$. Auditor merupakan suatu profesi yang menuntut untuk menjaga kepercayaan publik akan profesinya dalam bentuk menjaga dan mempertahankan akuntabilitasnya. Dalam mempertanggungjawabkan tindakannya kepada pihak-pihak yang berkepentingan menuntut auditor melakukan usaha audit yang tinggi. Semakin luasnya lingkup tanggungjawab pekerjaan yang dimiliki auditor, semakin besar akuntabilitas yang harus dimiliki seorang auditor. Newell dan Belour (2002) menyatakan bahwa akuntabilitas merupakan suatu keharusan lembaga-lembaga sektor publik untuk lebih menekan pertanggungjawaban horizontal (masyarakat) bukan hanya pertanggungjawaban vertikal (otoritas yang lebih tinggi). Fenomena yang ditunjukkan oleh penelitian ini mengindikasikan bahwa semakin tinggi akuntabilitas seorang auditor dapat meningkatkan kualitas audit yang dihasilkan, 
Putu Kemala Vidyantari dan I Dewa Gede Dharma Suputra. Pengaruh ...

dimana reward mampu memberikan pengaruh positif dalam meningkatkan kualitas audit yang dihasilkan.

Pada uji moderasi menunjukkan hasil reward memiliki kemampuan dalam memoderasi pengaruh kecerdasan emosional pada kualitas audit. Hasil ini menunjukkan bahwa reward memperkuat pengaruh kecerdasan emosional pada kualitas audit, dengan tingkat signifikansi nilai t sebesar 0,04 dan nilai koefisien regresi sebesar 0,435 Hal ini berarti bahwa reward mampu memoderasi pengaruh kecerdasan emosional pada kualitas audit, maka hipotesis keenam $\left(\mathrm{H}_{6}\right)$ diterima. Nilai koefisien regresi sebesar 0,454 menunjukkan reward sebagai variabel pemoderasi sifatnya memperkuat hubungan antara kecerdasan emosional pada kualitas audit.Hasil ini menerima hipotesis $\mathrm{H}_{6}$. Kompleksitas pekerjaan yang diemban seorang audior semakin membutuhkan kecerdasan emosionalnya. Tanpa kecerdasan emosional, seseorang tidak akan mampu menggunakan kemampuan kognitif mereka sesuai dengan potensi yang maksimum. Kecerdasan emosional yang dimiliki auditor menimbulkan sikap empati sehingga hal ini membuat auditor memilki tingkat responsif yang tinggi padakebutuhan kliennya dan mereka akan memotivasi diri untuk berkomitmen terhadap kualitas audit (Malyani dan Dwija, 2017). Fenomena dalam penelitian ini menunjukkan bahwa reward berperan sebagai pemotivasi kerja auditor untuk selalu mengerahkan kemampuannya dengan optimal baik itu kemampuan kompetensinya dan kemampuan mental yang ia miliki. Kemampuan auditor untuk mengelola diri sendiri, mampu bekerja dengan baik walaupun dalam tekanan, dan tidak membuat keputusan tergesa-gesa mencerminkan kecerdasan emosional seorang auditor. 


\section{SIMPULAN}

Berdasarkan hasil analisis dan pembahasan yang telah dilakukan sebelumnya, maka dapat ditarik simpulan sebagai berikut. 1) Due profesional care berpengaruh positif signifikan pada kualitas audit yang dimiliki oleh auditor di KAP Provinsi Bali. Semakin tinggi due pofessional care yang dimiliki oleh auditor dapat meningkatkan kualitas audit yang dihasilkan. 2) Akuntabilitas berpengaruh positif signifikan pada kualitas audit yang dimiliki oleh auditor di KAP Provinsi Bali. Semakin tinggi akuntabilitas seorang auditor dalam melakukan pengauditan dapat meningkatkan kualitas audit yang dihasilkan. 3)Kecerdasan emosional berpengaruh positif signifikan pada kualitas audit yang dimiliki oleh auditor di KAP Provinsi Bali. Semakin tinggi kecerdasan emosional seorang auditor dalam melakukan pengauditan dapat meningkatkan kualitas audit yang dihasilkan. 4) Reward memperkuat pengaruh due professional care, akuntabilitas, dan kecerdasan emosional pada kualitas audit dari auditor di KAP Provinsi Bali. Hal ini bermakna bahwa tingginya suatu due professional care, akuntabilits, dan kecerdasan emosional yang dimiliki auditor dapat meningkatkan kualitas audit serta dengan adanya pemberian reward maka memperkuat pengaruh ketiga variabel tersebut

Berdasarkan hasil penelitian dan simpulan maka saran yang dapat disampaikan adalah sebagai berikut. 1) Auditor di KAP Provinsi Bali diharapkan senantiasa selalu bekerja berdasarkan due professional care dengan meningkatkan sikap skeptis sehingga dapat melakukan evaluasi terhadap bukti audit sehingga mampu memberikan hasil laporan audit yang akurat dan 
berkualitas; 2) KAP yang telah melakukan evaluasi pada hasil pekerjaan juniornya diharapkan tetap mempertahankannya sehingga dapat menghasilkan laporan audit yang akurat dan berkualitas; 3) Auditor yang telah memiliki motivasi kerja yang tinggi tetap dipertahankan sehingga dapat melakukan penugasan secara optimal yang menghasilkan laporan audit yang berkualitas; 4) Penelitian ini menemukan bahwa reward dapat memperkuat due professional care, akuntabilitas, dan kecerdasan emosional pada kualitas audit. KAP yang telah memperhatikan pemberian reward bagi auditor diharapkan dapat mempertahankannya, sebab adanya pemberian reward dalam capaian kerja dapat meningkatkan motivasi auditor sehingga menghasilkan kualitas audit yang baik.

\section{REFERENSI}

Abdurrahman. 2014. Pengaruh Faktor Kompetensi, Stres Kerja dan Sistem Reward Terhadap Kinerja Auditor Eksternal Pemerintah (Studi Empiris pada BPK RI Perwakilan Provinsi Sulawesi Selatan). Skripsi. Makassar: Universitas Hasanuddin.

Agus S., Kd dan Yenni L., Md. 2016. Pengaruh Kecerdasan Intelektual, Kecerdasan Emosional, Kecerdasan Spiritual, Komitmen Organisasi Terhadap Kinerja Auditor. E-Jurnal Akuntansi Universitas Udayana Vol.17.2. November (2016): 1168-1195

Amerthajaya, Ny. T. N. dan Lely A., N. Kt. 2016. Pengaruh Teknik Audit Berbantuan Komputer, Due Professionalisme Care, Akuntabilitas, dan Kecerdasan Spiritual Pada Kualitas Audit. E-Jurnal Akuntansi Universitas Udayana Vol.17.2. November (2016) : 1603-1634

Ayu Puspita D. dan Dharma Suputra. 2016. Pengaruh Akuntabilitas, Karakteristik Personal Auditor, dan Skeptisme Profesional Pada Kualitas Audit. EJurnal Akuntansi Universitas Udayana . Vol.17.3.: 1780-1807

Amelia, Melli. 2009. Pengaruh Kecerdasan Emosional (Emotional Quotient) Auditor Ekesternal dan Kecerdasan Intelegensi (Intelegency Quotient) Auditor Eksternal Terhadap Kinerja Auditor Eksternal Dengan 
Kepercayaan Diri sebagai Variabel Moderating. Skripsi. Fakultas Ekonomi dan Ilmu Sosial Universitas Islam Negeri Syarif Hidayatullah

Badjuri, Achmat. 2011. Faktor-faktor yang Berpengaruh Terhadap Kualitas Audit Auditor Independen pada Kantor Akuntan Publik (KAP) di Jawa Tengah. Jurnal Dinamika Keuangan dan Perbankan, Nopember 2011, Hal: 183 197 Vol. 3, No. 2. ISSN :1979-4878

Cholifa, Saydah dan Suryono, Bambang. 2015. Pengaruh Due Professional Care, Akuntabilitas, dan Time Budget Pressure Terhadap Kualitas Audit. Jurnal Ilmu \& Riset Akuntansi Vol. 4 No. 2 (2015). Sekolah Tinggi Ilmu Ekonomi Indonesia (STIESIA) Surabaya

Darmawan, I.B. Angga B. dan Astika, I.B. Putra. 2017. Pengaruh Due Professional Care Pada Good Corporate Governance dan Implikasinya Pada Kualitas Audit Internal. E-Jurnal Akuntansi Universitas Udayana Vol.20.1. Juli (2017): 30-60

De Angelo, L.E. 1981. Auditor Independence, "Low Balling", And Disclosure Regulation. Journal Of Accounting And Economics vol. 3(2) :113-127

Elitzur, Ramy and Haim Falk (1996). Planned Audit Quality, Journal of Accounting and Public Policy, vol. 15:247-269

Febriyanti, R. 2014. Pengaruh Independensi, Due Professional Care, dan Akuntabilitas terhadap Kualitas Audit (Studi Empiris Pada Kantor AkuntanPublik di Kota Padang dan Pekanbaru). Jurnal. Fakultas Ekonomi Universitas Negeri Padang. Diakses pada 27 Juli 2017 http://ejournal.unp.ac.id/students/index.php/akt/article/viewFile/1529/1152

Goleman, Daniel. 2003. Emotional Intelligence (Terjemahan T Hermaya). Jakarta :PT Gramedia Pustaka Utama.

Hakim, Arif Rahman dan Esfandari, Amilia Yunizar. 2015. Pengaruh Kecerdasan Intelektual, Kecerdasan Emosional, Pengalaman Auditor, dan Due Professional Care Terhadap Kualitas Audit (Studi Empiris pada Kantor Akuntan Publik di Wilayah Jakarta Barat dan Jakarta Selatan). Jurnal Akuntansi dan Keuangan Vol. 4 No. 1 April 2015. Fakultas Ekonomi Universitas Budi Luhur

Henriansyah, Muhammad Iqbal, Taufeni Taufik, dan Vince Ratnawati. 2016. Pengaruh Reward sebagai Variabel Moderasi dengan Kompetensi, Independensi, Pengalaman Kerja, dan Keahlian Profesional terhadap Kualitas Audit. Jurnal SOROT. 11(1), hal: 1-14 
Jaya, I Made Indra dkk. 2016. Pengaruh Kecerdasan Emosional dan Budaya Kerja Terhadap Kualitas Audit di Pemerintah Daerah Bali (Studi Empiris pada 3 Kantor Inspektorat di Provinsi Bali). Jurnal Akuntansi Vol: 6 No: 3 Tahun 2016. Universitas Pendidikan Ganesha

Jensen \& Meckling. 1976. The Theory of The Firm: Manjerial Behaviour, Agency Cost, and Ownership Structure. Journal of Financial and Economics, 3:305-360

Krisna, Md dan Budiartha, Kt. 2017. Etika Auditor Sebagai Pemoderasi Pengaruh Pengalaman Auditor, Kompetensi, dan Due Professional Care pada Kualitas Audit. E-Jurnal Akuntansi Universitas Udayana. Vol.20.1. Juli (2017): 615-644.

Louwers, Ponemon, L. A., \& Radtke, R. R. (1997). Examining accountants ethical behaviour: A review and implication for future research. American Accounting Association.

Malyani R, I.G.A dan Asri Dwija P,I.G.A.M. 2017. Pengaruh Kecerdasan Intelektual, Kecerdasan Emosional, Kecerdasan Spiritual, Independensi, dan Komitmen Organisasi Pada Kinerja Auditor. E-Jurnal Akuntansi Universitas Udayana Vol.20.1. Juli (2017): 814-844

Meidawati, Neni. 2001. Meningkatkan Akuntabilitas Auditor Independen Melalui Standar Profesional. Artikel. Media Akuntansi Edisi 16-Januari-Februari

Maslow, Abraham H. 2010. Motivation and Personality. Rajawali, Jakarta.

Newell, S. and P.Bellour. 2002. Mapping Accountability: Origins, Contexts and Implications for development. Institute of Development Studies: England. IDS Working Paper 168.

Patton, P. 1998. Kecerdasan Emosional di Tempat Kerja Alih Bahasa : Zaini Dahlan. Jakarta: Pustaka Delaprata

Pujianto, Wahyu Eko. 2013. Pengaruh Sistem Pengukuran Kinerja dan Sistem Reward Terhadap Total Quality Management dan Kinerja Managerial pada Mic Transformer Surabaya. Jurnal. 1(2), hal: 187-202

Putri, Agni Widianing. 2015. Pengaruh Pengalaman Kerja, Kompetensi, Independensi, Akuntabilitas, Profesionalisme, Kompleksitas Tugas, dan Etika Auditor Terhadap Kualitas Audit (Studi Empiris pada BPK-RI Perwakilan Provinsi Jawa Tengah). Skripsi. Fakultas Ekonomi Universitas Muria Kudus 
Rizky A., Natasha dan Wirakusuma, Made Gede. 2016. Pengalaman Kerja sebagai Pemoderasi Pengaruh Due Profesional Care Pada Kualitas Audit. E-Jurnal Akuntansi Universitas Udayana Vol.17.1. Oktober (2016): 1-28. Fakultas Ekonomi dan Bisnis Universitas Udayana

Robbins, Stephen T. 2003. Perilaku Organisasi Terjamahan Ahmad Fausi, 2006. Klaten: Indeks.

Singgih, E.M dan Bawono, Icuk, R. 2010. Jurnal. Pengaruh Independensi, Pengalaman, Due Care Profesional Terhadap Kualitas Audit. SNA 13 UNSOED. Purwokerto.

Sugiyono. 2013. Metode Penelitian Bisnis. Bandung: C.V. Alfabeta

Swari, Candra Mitha. Putu dan Ramantha. 2013. Pengaruh Independensi dan Tiga Kecerdasan Terhadap Pertimbangan Pemberian Opini Auditor. E-Jurnal Akuntansi Universitas Udayana 4.3 (2013): 489-508

Srinidhi, Bin dan Ferdinand A Gul. 2006. The Differential Effect of Auditors non audit and Rewards on Accrual Quality. Melalui http:// papers. ssrn. com/ s013/JELJOURResults.cfm?fromname=journalBrowse $\&$ journalid=845731. [24/2/2012].

Zawitri, S. 2009. Analisis Faktor-Faktor Penentu Kualitas Audit Yang Dirasakan dan Kepuasan Auditee di Pemerintahan Daerah. Tesis. Program Magister Akuntansi Universitas Diponegoro. Semarang 